\title{
Performance of the DNA-Citoliq liquid-based cytology system compared with conventional smears
}

\author{
V. A. F. Alves ${ }^{* \dagger}$, A. Castelo ${ }^{\star}$, A. L. Filho ${ }^{\dagger, \S}$, M. R. Vianna ${ }^{\uparrow}$, E. Taromaru**, G. Namiyama ${ }^{\dagger}$, \\ A. Lorincz ${ }^{\dagger \dagger}$ and G. B. D. Dores** for the DNA-Citoliq Working Group, São Paulo, Brazil ${ }^{1}$ \\ *School of Medicine, São Paulo University, São Paulo, Brazil, `Adolfo Lutz Institute, São Paulo, Brazil, ‘School of Medicine, \\ Federal University of São Paulo, São Paulo, Brazil, ${ }^{\$}$ Health Sciences School, Minho University, Braga, Portugal, "Surgical \\ Pathology Laboratory, Hospital Alemao Oswaldo Cruz, Sao Paulo, Brazil, **Digene Brasil, São Paulo, Brazil and ${ }^{\dagger \dagger}$ Digene \\ Corporation, Gaithersburg, MD, USA
}

Accepted for publication 13 June 2005

V. A. F. Alves, A. Castelo, A. L. Filho, M. R. Vianna, E. Taromaru, G. Namiyama, A. Lorincz and G. B. D. Dores for the DNA-Citoliq Working Group, São Paulo, Brazil

Performance of the DNA-Citoliq liquid-based cytology system compared with conventional smears

Objective: To evaluate the performance of a new, manual, simplified liquid-based system, DNA-Citoliq (Digene Brasil), employed under routine conditions as compared to conventional smears collected from six collaborating private laboratories.

Methods: A panel of cytopathologists, who served as the gold standard diagnosis, adjudicated discordant opinions.

Results: Of 3206 pairs of slides considered valid for comparison, there were 3008 in full agreement (93.8\%), $112(3.5 \%)$ with one diagnostic category discrepancies, and $86(2.7 \%)$ discordant cases. Among the 288 borderline+ by either method, DNA-Citoliq detected abnormalities in 243 (84.4\%), and conventional smears (CS) detected abnormalities in $178(61.8 \%)$ (McNemar test, $P<0.000)$, a 36.5\% increased detection of borderline+ cases.

Conclusions: For mild dyskaryosis, DNA-Citoliq detected 176 cases and CS 125 cases (McNemar test, $P<0.000)$; and for moderate+severe dyskaryosis 66 versus 32 cases respectively (McNemar test, $P<0.000)$.

Keywords: liquid-based cytology, DNA-Citoliq system, thin layer cytology, split-sample study, severe dyskaryosis, HPV

\section{Introduction}

Liquid-based cytology (LBC) has become an important tool in uterine cervix cytopathology. ${ }^{1-3}$ Many split-

Correspondence:

Dr Venancio Avancini Ferreira Alves, Pathology Division, Adolfo Lutz Institute, Dr Arnaldo Ave, 355-Cerqueira Cezar, 01246-902, São Paulo, SP, Brazil.

Tel.: +55 113068 2875; Fax: +55 11 2882421;

E-mail: venancio@uol.com.br

${ }^{1}$ Other members of the DNA-Citoliq Working Group, to be credited as co-authors: S. Maeda, M. S. B. Leite, E. F. Miziara, A. P. Pinto, A. L. M. A. Horta, J. L. Portugal, C. A. Ribeiro and R. Luzzatto samples and direct-to-vial studies have shown higher detection rates of both low-grade and high-grade intra-epithelial lesions than conventional smears with either of the two FDA-cleared systems, ThinPrep ${ }^{\circledR}$ (Cytyc Corp., Boxborough, MA, USA) and SurePath (TriPath Imaging, Inc., Elon College, NC, USA)., Besides identifying minor morphological peculiarities, readily identifiable after a short training course, a major problem for wider adoption of LBC has been the increased costs of LBC. ${ }^{2}$

Mielzynska-Lohnas et al. ${ }^{6}$ reported on the development of a Universal Collection Medium (UCM), a useful solution for preservation of both nucleic acids and morphology. A new, simplified manual system for simultaneous preparation of up to 12 slides fixed in UCM has been developed by Digene Brasil (Sao Paulo, 
Brasil). The system, known as the DNA-Citoliq system (DNA-Citoliq), yields thin layer preparations, with preservation of the morphological characteristics of the uterine cervix epithelial cells, either normal or neoplastic. $^{7}$

The objective of the present study was to assess the performance of DNA-Citoliq in the detection of cervico-vaginal epithelial lesions under routine conditions in six Brazilian private cytopathology laboratories.

\section{Methods}

A convenience study of 3271 samples, collected from women who attended clinics at the six collaborating laboratories for a routine cervical smear, either for their annual screening or during a gynaecological examination, was performed from September 2001 to April 2002.

Women with at least one of the following criteria were excluded: previous uterine cervix surgery, pregnancy and refusal to participate.

\section{Conventional smear and DNA-Citoliq procedures}

Participating laboratories received a 1-day workshop to train technicians and cytopathologists on technical procedures, and compliance with the Technical Manual. In total, 3271 'pairs' of samples were collected and prepared in six different private Brazilian laboratories: CIAP (Brasilia), Instituto de Patologia (Porto Alegre), Instituto Roberto Alvarenga (Belo Horizonte), Annalab (Curitiba), Biocito (Goiania), and Salomão \& Zoppi (São Paulo). Material for the conventional Pap test was always collected first with the aid of an Ayre's wooden spatula scraping the ectocervix and a conical Digene brush for the endocervix. The material collected was immediately smeared on a slide and alcohol-fixed. Afterwards, the same conical brush with residual endocervical sample was used for brushing the ectocervix. The brush was then inserted into a plastic tube with $1.0 \mathrm{ml}$ of UCM, the brush shaft was broken at the marked area, and the tube was capped and gently shaken for 30 seconds.

The slide preparation followed the DNA-Citoliq Protocol already reported. ${ }^{8}$ In short, the system consists of an aluminium device, Prepgene (weight $3 \mathrm{~kg}$ with dimension of $37 \times 10 \times 4 \mathrm{~cm}$ ), developed to hold Duogene, which contains a slide holder (Lamigene) and a filter holder (Filtrogene). Lamigene is made of polypropylene, holds 12 cytological slides, and Filtrogene has a high-density polystyrene base, to which a strip of absorbent material (with 12 polycarbonate membranes) is attached. These membranes are $25 \mathrm{~mm}$ in diameter with a 5 - $\mu \mathrm{m}$ pore size. Slides from samples collected in UCM are manually prepared using Prepgene, a high-resistance aluminium alloy, with tight fittings with Lamigene on the upper part and Filtrogene on the lower part. By locking the system laterally, the slides are fixed and compressed against Filtrogene.

Briefly, the steps in slide preparation are:

- mix each tube thoroughly by vortexing individually at high speed for 15 seconds;

- immediately before pipetting, vortex again for 5 seconds:

- remove the tube cap, and pipette $200 \mu \mathrm{L}$ of the UCM specimen;

- dispense the specimen onto the polycarbonate membrane, spreading the liquid uniformly on the entire membrane area;

- close and lock the Prepgene lid, and wait for 10 seconds. During this step, the cells are imprinted from the membrane to the glass slide;

- unlock and raise the Prepgene lid backwards carefully;

- remove Lamigene and fix the slides with spray fixative, or fully dip Lamigene in an appropriate container with absolute alcohol;

- perform Papanicolaou stain;

- after use dispose of Lamigene and Filtrogene in a biohazard waste container.

Criteria for slide review and definitions of the final diagnoses

All cases were primarily assessed according to the Brazilian Health System/Brazilian Society of Cytopathology Nomenclature (1994), based on WHO classification of squamous lesions in three classes (CIN1, 2 and 3), ${ }^{9}$ with the addition of criteria for sample quality assessment from the Bethesda 2001 NCI Consensus. ${ }^{10}$ Presently, all diagnoses were reported according to the United Kingdom British Society for Clinical Cytology (BSCC) classification. ${ }^{11,12}$

Conventional smears and DNA-Citoliq slides were coded and studied separately by the cytopathologist from each laboratory. Whenever both samples of the pair were considered adequate and diagnosed as negative, the slide was not referred to the reference laboratory, except when included in the $5 \%$ random sample used for quality control. Both conventional 
and DNA-Citoliq samples were assessed blinded by the screeners.

In order to be deemed adequate, the slide should have an estimated minimum of at least 8000/12 000 cells for the conventional smear and 5000 for LBC, as proposed by the Bethesda system. ${ }^{10}$ Preparations with more than $75 \%$ of squamous cells obscured by factors such as inflammatory cells and red blood cells were considered unsatisfactory.

All cases fulfilling at least one of the following criteria had both slides of the pair submitted to a review at the central laboratory:

1 Unsatisfactory sample: whenever one slide of the pair was considered unsatisfactory, both slides were submitted to review.

2 Presence of significant abnormalities: borderline, mild, moderate or severe dyskaryosis and invasion.

3 Presence of glandular atypia, in situ (AIS) or invasive adenocarcinoma (Adenoca).

4 Diagnostic category discrepancies in each sample of the pair.

5 Five per cent of cases diagnosed as negative, randomly selected for review.

6 Cases in which the cytopathologist of the original laboratory asked for a second opinion.

In cases where both the primary and the reference laboratories reached the same diagnosis this was considered the definitive diagnosis. Whenever discordant, a definitive diagnosis was obtained by consensus from a panel of all cytopathologists involved in the project by examining the cases with a multi-head microscope.

\section{Statistical analysis}

The significance of differences in the rates of detection of abnormalities between the two systems of sample preparation was examined by the McNemar test (two-category data) at a significance level of $P<0.05$. Confidence intervals were calculated.

\section{Results}

\section{Sample adequacy}

The 3271 specimens are the basis for our analysis. Samples prepared according to the DNA-Citoliq procedure were, in the vast majority of cases, well distributed in the $25 \mathrm{~mm}$ diameter circle, with extensive thin-layered areas, although groups of crowded cells were also seen. Conventional smears were satisfactory in $99.7 \%$ of the samples and unsatisfactory in $0.3 \%$ [95\% confidence interval (CI): $0.1-$ $0.6 \%$ ]. Residual samples processed by DNA-Citoliq were satisfactory in $98.2 \%$ and unsatisfactory in $1.8 \%$ (95\% CI $1.4-2.4 \%$ ). The most relevant factors for inadequacy of a sample were hypocellularity, reported in 20 slides, cellular overlapping obscuring more than $75 \%$ of the slide in 13 cases, clumped red blood cells in 11 and clusters of leucocytes in nine slides.

\section{Squamous cell lesions}

Cellular features were well defined in DNA-Citoliq samples. Cell membranes and cellular contours were evident and smooth, and cytoplasmic volume and staining properties followed classical patterns of cytology. Clarity of nuclear shape and chromatin distribution were conducive to a detailed evaluation of cytodiagnostic criteria for each pattern of epithelial lesion. Diagnostic cells were numerous in many abnormal cases. Koilocytes were remarkable, with clear-cut perinuclear halos and nuclear atypia. Nuclear cytoplasmic ratio and chromatin texture of squamous intraepithelial lesions (SIL) lesions were evident, as depicted in Figure 1. Severley dyskaryotic cells were, in several cases, smaller than usual, with basophilic cytoplasm and central nuclei showing irregular contours and coarse chromatin. Occasionally cells with severe dyskaryosis were seen in crowded

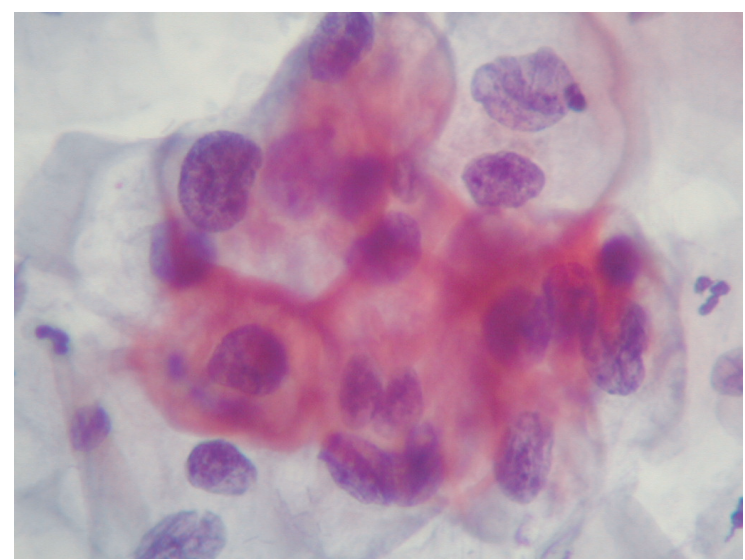

Figure 1. Cellular features of major lesions in DNA-Citoliq samples: koilocytes present as large cells with sharp cell membranes, clear cytoplasm and enlarged nuclei with mild chromatin atypia. 


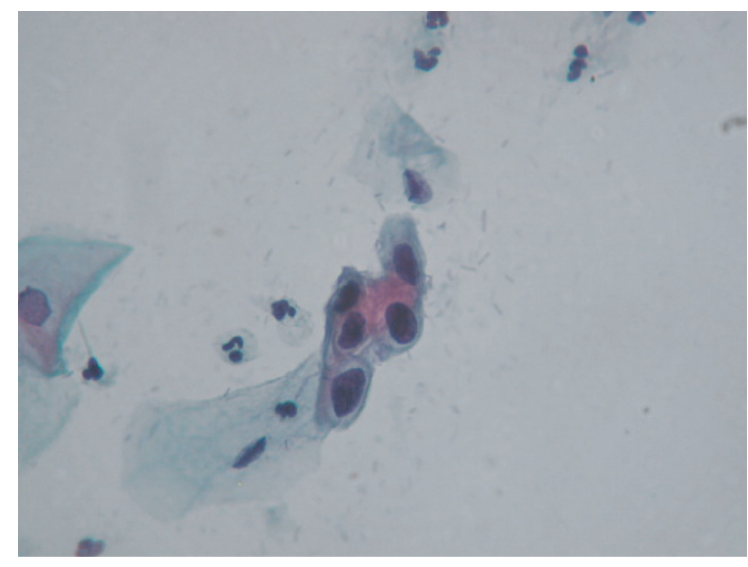

Figure 2. Cellular features of major lesions in DNA-Citoliq samples: moderate dyskaryosis cells may look smaller than those seen at conventional smear. Moderate increase in nuclear to cytoplasm ratio and chromatin distribution are characteristic.

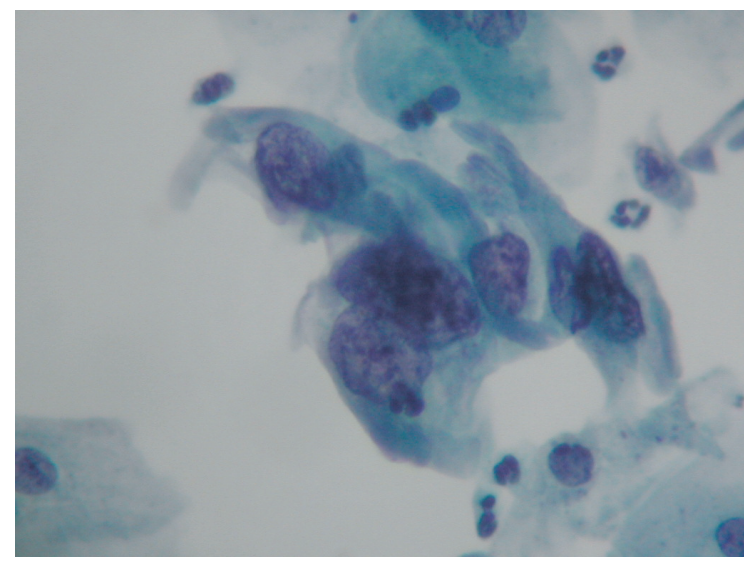

Figure 3. Cellular features of major lesions in DNA-Citoliq samples: dyskaryotic cells depicting large nuclei, with coarse chromatin, irregularly distributed.

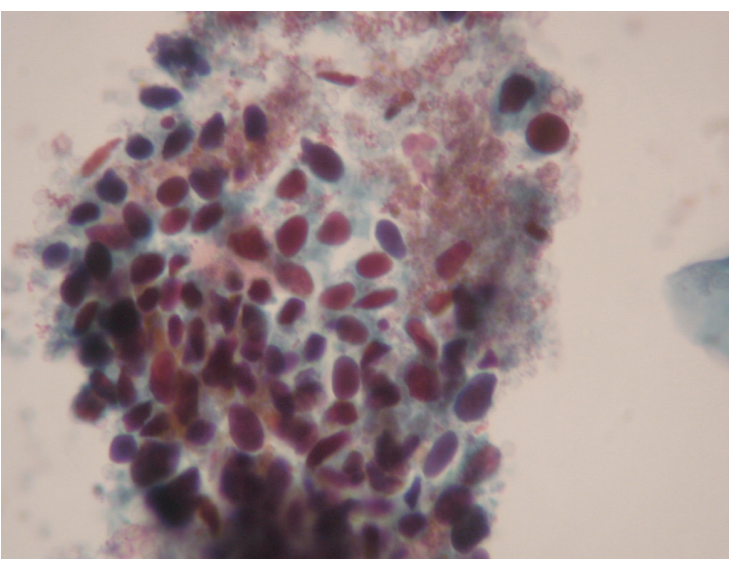

Figure 4. Cellular features of major lesions in DNA-Citoliq samples: invasive squamous cell carcinoma with small and medium-sized cells, some of them almost devoid of cytoplasm, with spindle, oval or round nuclei with severely distorted chromatin. Haemorrhagic background is condensed in clumps.

clusters, resembling coarse groups of undifferentiated cells, with a small rim of cytoplasm (Figures 2 and 3).

In the four cases diagnosed as invasive squamous cell carcinoma with DNA-Citoliq, eosinophilic keratinized cytoplasm, large nuclei with irregular contours and chromatin clumps were observed. Cell size and shape were variable, and several spindle cells were seen. DNA-Citoliq samples, in contrast to conventional smears, showed several fields with neoplastic cells on a clean background. Occasionally, tumour diathesis consisting of cellular debris, leucocytes and red blood cells were found in clumps (Figure 4).

Table 1 illustrates the comparison among the diagnoses of squamous cell lesions achieved by DNACitoliq and conventional smears. Of 3206 adequate pairs of slides there was full agreement in $93.8 \%$

Table 1. Comparison of diagnostic performance of DNA-Citoliq system versus conventional smears for detection of squamous abnormalities

\begin{tabular}{lrrrrrrr}
\hline \multicolumn{7}{l}{ DNA-Citoliq } \\
\cline { 2 - 7 } Conventional & Negative & Borderline & Mild dyskaryosis & Moderate dyskaryosis & Severe dyskaryosis & Invasion & Total \\
\hline Negative & 2918 & 44 & 38 & 16 & 12 & 0 & 3028 \\
Borderline & 31 & 12 & 7 & 1 & 2 & 0 & 53 \\
Mild dyskaryosis & 14 & 8 & 56 & 12 & 6 & 0 & 90 \\
Moderate dyskaryosis & 0 & 2 & 5 & 0 & 13 & 0 & 17 \\
Severe dyskaryosis & 0 & 1 & 0 & 0 & 31 & 3 & 3 \\
Invasion & 0 & 0 & 0 & 35 & & 4 & 3206 \\
Total & 2963 & 67 & 106 & & & & \\
\hline
\end{tabular}


(3008), a one-category discrepancy in 3.5\% (112), and a discrepancy of two or more diagnostic categories in $2.7 \%(86)$ of the pairs. Among the 288 women considered 'abnormal' (borderline or greater) by either method, DNA-Citoliq was abnormal in 243 (84.4\%) when compared with $178(61.8 \%)$ for the conventional smears $($ McNemar test, $P<0.000)$. There were many diagnostic discrepancies between DNA-Citoliq and the conventional smear. For example, of 106 specimens identified as mild dyskaryosis by DNACitoliq, 38 were called negative on the conventional smear. Conversely, of 90 specimens diagnosed as mild dyskaryosis on the conventional smear, 14 were classified as negative by DNA-Citoliq. Remarkably, of 66 moderate/severe dyskaryosis lesions diagnosed by DNA-Citoliq $28(42 \%)$ were classified as negative by conventional smear. By contrast, of 32 cases diagnosed as moderate/severe dyskaryosis by the conventional smear, DNA-Citoliq classified three as borderline and five as mild dyskaryosis but none were called negative (Table 1).

Considering all specimens categorized as borderline+, DNA-Citoliq detected 243, whereas conventional smears identified 178 of these specimens (McNemar test, $P<0.0001$ ), giving an increase in detection of abnormalities of $36.5 \%$ for DNA-Citoliq versus the conventional smear. The borderline/dyskaryosis ratio was $0.43(53: 122)$ with the conventional smears and 0.39 (67: 172) with DNA-Citoliq.

As shown in Table 2, when the cut-off for the comparison was mild dyskaryosis+, DNA-Citoliq detected 176 cases whereas 125 such cases were detected in conventional smears (McNemar test, $P<0.000)$, thus representing an incremental detection of $40.8 \%$. Regarding moderate dyskaryosis or greater (severe dyskaryosis and invasion), DNA-

Table 2. Diagnostic performance of DNA-Citoliq system and conventional smears for detecting squamous abnormalities. Positive case defined as mild or more severe dyskaryosis

\begin{tabular}{lrcr}
\hline & \multicolumn{3}{l}{ DNA-Citoliq } \\
\cline { 2 - 4 } Conventional & Positive & Negative & Total \\
\hline Positive & 100 & 25 & 125 \\
Negative & 76 & 3005 & 3081 \\
Total & 176 & 3030 & 3206 \\
DNA-Citoliq mild dyskaryosis+ & 176 & $5.5 \%$ & \\
Conventional mild dyskaryosis+ & 125 & $3.9 \%$ & \\
Increment & 51 & $40.8 \%$ & \\
\hline
\end{tabular}

$P<0.00001$.
Table 3. Diagnostic performance of DNA-Citoliq system and conventional smears for detecting squamous abnormalities. Positive case defined as moderate/severe dyskaryosis

\begin{tabular}{llcr}
\hline & \multicolumn{3}{l}{ DNA-Citoliq } \\
\cline { 2 - 4 } Conventional & Positive & Negative & Total \\
\hline Positive & 27 & 8 & 35 \\
Negative & 43 & 3128 & 3171 \\
Total & 70 & 3136 & 3206 \\
DNA-Citoliq moderate/severe & 70 & $2.2 \%$ & \\
$\quad$ dyskaryosis+ & & & \\
$\begin{array}{l}\text { Conventional moderate/severe } \\
\quad \text { dyskaryosis+ }\end{array}$ & 35 & $1.1 \%$ & \\
Increment & & & \\
\hline
\end{tabular}

$P<0.0001$.

Table 4. Diagnostic performance of DNA-Citoliq system and conventional smears for detecting glandular abnormalities

DNA-Citoliq

Adeno-

Conventional Negative Borderline AIS carcinoma Total

\begin{tabular}{lrlllr}
\hline Negative & 3174 & 7 & 0 & 0 & 3181 \\
Borderline & 22 & 1 & 0 & 0 & 23 \\
AIS & 0 & 0 & 1 & 0 & 1 \\
Adenocarcinoma & 0 & 0 & 0 & 1 & 1 \\
Total & 3196 & 8 & 1 & 1 & 3206 \\
\hline
\end{tabular}

AIS, atypia in situ.

Citoliq detected 70 cases, whereas only 35 cases were identified by conventional smears $(P<0.000)$, corresponding to a $100 \%$ increased detection, as shown in Table 3. 'High-grade' lesions (moderate and severe dyskaryosis) were detected in 66 cases by DNACitoliq, whereas only 32 cases were identified by conventional smears (McNemar test, $P<0.000)$. Among four cases diagnosed as invasive squamous cell carcinoma by DNA-Citoliq, three were also detected as such by conventional smear, and one case was diagnosed as severe dyskaryosis.

\section{Glandular epithelial lesions}

Endocervical cells were, in most cases, well represented in DNA-Citoliq samples, either as single cells or as groups of well-preserved cells (Table 4). However, this population included only one case with in situ adenocarcinoma and one case with invasive adenocarcinoma, both detected by both methods. Glandular 
borderline lesion was reported in 23 conventional smears and in eight DNA-Citoliq samples $(P=0.13)$.

\section{Discussion}

This study is the first assessment of the diagnostic performance of the new DNA-Citoliq system, based on a split-sample comparison. The final diagnosis (gold standard) in the present study was not based on histology but on a strict algorithm, with all discordant cases submitted to a panel of cytopathologists for the 'consensus diagnosis'. Thus, the increased number of cases detected by DNA-Citoliq system must be regarded as presumptive disease rather than definite lesions. DNA-Citoliq preparations detected 36.5\% more borderline+ than conventional smears. Similarly, mild dyskaryosis+ was also more often detected $(40.8 \%)$, as well as moderate/severe dyskaryosis+ $(100 \%)$.

When assessing new diagnostic systems for cervicovaginal screening it is recommended that a wellestablished method be concomitantly used to avoid any diagnostic inaccuracy that could potentially harm the patient. ${ }^{13-17}$ Accordingly, the protocol was designed prioritizing the conventional smear, i.e. an additional sample for the new method would be taken immediately after collecting material for the routine smear. Bishop ${ }^{13}$ observed an increased level of detection of SIL with the Auto-Cyte LBC (86.7\%) versus the conventional smear $(63.6 \%)$. These findings were subsequently confirmed in several other reports ${ }^{14-17}$ and in a multicentre study, ${ }^{18}$ where the Auto-Cyte system detected $31 \%$ more dyskaryosis in relation to the conventional smears. Experience with ThinPrep ${ }^{\circledR}$, another liquid-based system, also demonstrated $87.8 \%$ detection of mild dyskaryosis versus $68.1 \%$ with conventional smears. ${ }^{14}$

Two studies have assessed both the sensitivity and specificity of ThinPrep ${ }^{\circledR} \cdot{ }^{19,20}$ The first study ${ }^{19}$ compared ThinPrep ${ }^{\circledR}$ versus conventional smear to diagnose mild or more severe dyskaryosis using histology as the reference standard. Sensitivity of 0.94 and specificity of 0.58 was reported for ThinPrep ${ }^{\circledR}$, whereas conventional smears had a sensitivity of 0.85 and a specificity of 0.36. Another study ${ }^{20}$ also compared ThinPrep ${ }^{\circledR}$ and conventional smears in a split-sample study. Positive cases on either test were verified either cytologically or histologically; histological verification was obtained on a majority of severe dyskaryosis samples. The relative true positive rate was 1.13 , indicating that ThinPrep ${ }^{\circledR}$ had higher sensitivity, and the relative false-positive rate was 1.12 , translating as a slightly lower specificity of ThinPrep ${ }^{\circledR}$.

A more accurate evaluation of the performance of DNA-Citoliq would be to randomize women to be examined either by DNA-Citoliq or by conventional smear. Through this approach, known as 'direct-tovial', each method has an equal opportunity to work with representative cervico-vaginal samples. ${ }^{1}$ The detection of both low- and high-grade lesions seems to be substantially improved by LBC. ${ }^{5,20-23}$ Indeed, a direct-to-vial comparison study ${ }^{21}$ reported $1.58 \%$ detection rate of mild dyskaryosis with conventional smears and $2.52 \%$ in Auto-Cyte. In the same study, moderate/severe dyskaryosis was detected in $0.38 \%$ with conventional smears and in $0.68 \%$ of Auto-Cyte. Another direct-to-vial study ${ }^{23}$ with Auto-Cyte in relation to conventional smear has confirmed the increased detection of mild dyskaryosis (57\%) and moderate/ severe dyskaryosis (55\%). Thus, based on the experience with other LBC methods, ${ }^{5,20-23}$ one could anticipate that further improvement of lesion detection and sample adequacy would be even higher in a direct-tovial study. An important aspect in studies dealing with comparisons of test performance of cervico-vaginal cytology is the nature of the 'gold standard' for the diagnosis. Due to logistical constraints, systematic biopsy of all abnormal cytological results was not possible in our study. Histological correlation clearly demonstrated that dyskaryotic lesions detected with LBC in excess of conventional smears were usually not false positives. ${ }^{24}$ Therefore, follow-up histology-based DNA-Citoliq studies are warranted.

Screeners received a 3 -day training in preparation for the study. Not surprisingly, the DNA-Citoliq rate $(1.8 \%)$ of unsatisfactory samples was quite similar to other LBC. ${ }^{25}$ We would have expected the proportion of inadequate samples to be lower had the specimen for DNA-Citoliq slide not been taken after collecting material for the conventional smear. A rather remarkable adequacy rate found with the conventional method could possibly be attributed to examiners' awareness of their participation in a multicentre investigation.

Cytomorphology of epithelial cells was well defined, leading to a prompt recognition of abnormal cells. Moderate/severe dyskaryotic cells smaller than usually detected in conventional smears were sometimes observed. This feature, also reported in the ThinPrep ${ }^{\circledR}$ samples, could be ascribed to the fixative solution. As previously reported, UCM used in the DNA-Citoliq System uses an N-butanol-based liquid. Columnar 
epithelial cells, both individually or in sheets, were well represented and morphologically well preserved. The low incidence of glandular cell abnormalities in the present population prevented the appropriate evaluation of DNA-Citoliq performance in such lesions. As residual endocervical material was used to prepare DNA-Citoliq slides, this could explain the lower frequency of glandular borderline lesions when compared with conventional smears.

A major reason for the advances achieved through LBC techniques is the fixative liquid, which, in the DNA-Citoliq system is UCM. The properties of UCM have been presented previously ${ }^{6,7}$ Besides yielding a crisp cytomorphological presentation and showing a retention of morphological details for at least 15 days after collection of the specimens, even at high temperatures in several cities in Brazil where the participating laboratories are located, UCM has been shown to be efficient in preserving nucleic acids, enabling the detection of HPV DNA either by Hybrid $^{\text {Capture }^{6}}$ or by PCR. ${ }^{26}$ Our preliminary, unpublished data also point to an excellent preservation of cellular antigens in immunocytochemical assays, as recently reported by Freitas et al. ${ }^{27}$ in cell blocks from samples fixed with Thin-Prep ${ }^{\circledR}$ fixative.

Concerns about the costs of LBC have been expressed in recent literature. Although Sulik et al. ${ }^{28}$ considered that new evidence should be provided regarding its cost-benefit ratio, several authors present impressive data on the potential global reduction of costs of programmes employing LBC for detection of pre-neoplastic cervical lesions. Advantages of LBC include higher sensitivity, the possibility for repeating the cytological preparations if needed and the ready availability of material for human papillomavirus testing without requiring another clinic visit by the patient. The preparation of each lot of 12 slides of DNA-Citoliq system requires 7-9 minutes of hands-on technical time. However, the screening time is reduced, in line with a recent report by Hoerl et al. ${ }^{29}$

In conclusion, the manual, liquid-based DNACitoliq system enabled the detection of a significantly higher number of squamous lesions. Most notably, DNA-Citoliq detected twice as many highgrade lesions as the conventional smear in our population of women. Future studies should assess cases with histological confirmation, whereas glandular lesions should be studied in populations with high risk for adenocarcinoma.

\section{References}

1. Cohn DE, Herzog TJ. New innovations in cervical cancer screening. Gynecol Surg Oncol 2001;44:538-49.

2. Ferenczy A, Franco E. Cervical cancer screening beyond the year 2000. Lancet Oncol 2001;2:27-32.

3. Gupta KP, Baloch ZW, Cobbs C, Bibbo M. Processing liquid-based gynecologic specimens. Comparison of the available techniques. Acta Cytol 2001;45:995-8.

4. Vassilakos P, Griffin S, Megevand E, Campana A. CytoRich liquid-based cervical cytologic test. Screening results in a routine cytopathology service. Acta Cytol 1998;42:198-202.

5. McCrory D, Matchar DB, Bastian L et al. Evaluation of Cervical Cytology. Evidence Report/Technology Assessment Number 5. Duke University, 290-97-0014; Agency for Health Care Policy and Research, 99-E010. Rockville, MD: Agency for Health Care Policy and Research; 1999.

6. Mielzynska-Lohnas I, Tang Y, Zhul J et al. Universal Collection Medium (UCM): a versatile medium for cytology, HPV DNA testing, and HPV RNA testing from a single patient specimen. Abstract Book. 4th International Multidisciplinary Congress, Eurogin, 2000, p. 74.

7. Alves VAF, Bibbo M, Schmitt FCL, Milanezi F, Longatto Filho A. Comparison of manual and automated methods of liquid-based cytology. A morphologic study. Acta Cytol 2004;48:187-93.

8. Alves V, Castelo A, Longatto Filho A, Vianna MR, Taromaru E, Dores GB, for the DNA-Citoliq Working Group. DNA-Citoliq SYSTEM (DNA-Citoliq): a new liquid-based system for cytology and molecular tests technical aspects. 20th International Papillomavirus Conference, Paris, 2002.

9. Scully RE, Bonfilgio TA, Kurman RJ, Silverberg SG, Wilkinson EJ. Histological Typing of Female Genital Tract Tumours, 2nd edn. World Health Organization, International Histological Classification of Tumours. Berlin, Heidelberg, New York: Springer-Verlag; 1994.

10. Solomon D, Davey D, Kurman R, for the Forum Group Members and the Bethesda 2001 Workshop. The Bethesda 2001 System: terminology for reporting results of cervical cytology. JAMA 2002;287:2114-9.

11. Evans DM, Hudson EA, Brown CL et al. Terminology in gynaecological cytopathology: report of the Working Party of the British Society for Clinical Cytology. J Clin Pathol 1986;39:933-44.

12. British Society for Clinical Cytology (BSCCC). Borderline nuclear changes in cervical smears: guidelines on their recognition and management. J Clin Pathol 1994;47:48192.

13. Bishop JW. Comparison of the CytoRich system with conventional cervical cytology. Preliminary data on 2032 cases from a clinical trial site. Acta Cytologica 1997;41:15-23. 
14. Bishop JW, Bigner SH, Colgan TJ et al. Multicenter masked evaluation of Autocyte PREP thin layer with matched conventional smears. Including initial biopsy results. Acta Cytol 1998;42:189-97.

15. Monsonego J, Autillo-Touati A, Bergeron C et al. Liquidbased cytology for primary cervical cancer screening: a multi-center study. Br J Cancer 2001;84:360-6.

16. Minge L, Fleming M, Vangeem T, Bishop JW. Autocyte Prep System vs conventional cervical cytology. Comparison based on 2,156 cases. J Reprod Med 2000;45:17984.

17. Biscotti CV, O'Brien DL, Gero MA, Gramlich TL, Kennedy AW, Easley KA. Thin-layer Pap test vs. conventional pap smear. Analysis of 400 split-samples. J Reprod Med 2002;47:9-13.

18. Hessling JJ, Raso DS, Schiffer B, Callicott J Jr, Husain M, Taylor D. Effectiveness of thin layer preparations vs. conventional pap smear in a blinded, split-sample study. Extended cytologic evaluation. J Reprod Med 2001; 46:880-6.

19. Bolick DR, Hellman DJ. Laboratory implementation and efficacy assessment of the ThinPrep cervical cancer screening system. Acta Cytol 1998;42:209-13.

20. Roberts JM, Gurley AM, Thurloe JK, Bowditch R, Laverty CRA. Evaluation of the ThinPrep test as an adjunct to the conventional Pap smear. Med J Aust 1997; 167:466-9.

21. Vassilakos P, Saurel J, Rondez R. Direct-to-vial use of the AutoCyte PREP liquid-based preparation for cervicalvaginal specimens in three European laboratories. Acta Cytol 1999;43:65-8.
22. Tench W. Preliminary assessment of the AutoCyte PREP. Direct-to-vial performance. J Reprod Med 2000;45:912-6.

23. Marino JF, Fremont-Smith M. Direct-to-vial experience with AutoCyte PREP in a small New England regional cytology practice. J Reprod Med 2001;46:353-8.

24. Vassilakos P, Schwartz D, Marval F et al. Biopsy-based comparison of liquid-based, thin layer preparations to conventional Pap smears. J Reprod Med 2000;45:11-6.

25. Berstein SJ, Sanchez-Ramos L, Ndubisi E. Liquid-based cervical cytology smear study and conventional Papanicolaou smears: A metaanalysis of prospective studies comparing cytologic diagnosis and sample adequacy. Am J Obstet Gynecol 2001;185:308-17.

26. Nonogaki S, Wakamatsu A, Longatto Filho A et al. Hybrid capture II and polymerase chain reaction for identifying HPV infections in samples collected in a new collection medium. A comparison. Acta Cytol 2004;48:514-20.

27. Freitas C, Milanezi F, Dias AJ, Bento MJ, Schmitt FC. Use of cell block preparation for morphological, immunocytochemistry, and ploidy analysis in Thinprep monolayer preparations. Diagn Cytopathol 2001;25:415-7.

28. Sulik SM, Kroeger K, Schultz JK, Brown JL, Becker LA, Grant WD. Are fluid-based cytologies superior to the conventional Papanicolaou test? A systematic review. J Fam Pract 2001;50:1040-6.

29. Hoerl HD, Shalkham JE, Cheung K, Hurlbert SD, Inhorn SL, Kurtycz DF. Screening parameters for ThinPrep ${ }^{\circledR}$ and conventional gynecologic cytology via automated monitoring. Acta Cytol 2000;44:618-24. 